\title{
3D models related to the publication: Re-description of the braincase of the rebbachisaurid sauropod Limaysaurus tessonei and novel endocranial information based on CT scans
}

\author{
Ariana Paulina-Carabajal ${ }^{1 *}$, Jorge Calvo ${ }^{2}$ \\ ${ }^{1}$ Instituto de Investigaciones en Biodiversidad y Medioambiente (INIBIOMA), CONICET-Universidad Nacional del Comahue, Quintral 1250, 8400, San \\ Carlos de Bariloche, Argentina \\ ${ }^{2}$ Grupo de transferencia Proyecto Dino- Fac. Ingeniería-Museo Geología y Paleontología, Universidad Nacional del Comahue. Ruta prov. 51, km 65, \\ Neuquén, Argentina. \\ *Corresponding author: a.paulinacarabajal@conicet.gov.ar
}

\begin{abstract}
This contribution contains the 3D models described and figured in the following publication: Paulina-Carabajal A and Calvo JO 2021. Re-description of the braincase of the rebbachisaurid sauropod Limaysaurus tessonei and novel endocranial information based on CT scans. Anais da Academia Brasileira de Ciências 93(Suppl. 2): e20200762 https://doi.org/10.1590/0001-3765202120200762
\end{abstract}

Keywords: Cranial endocast, Dinosauria, Inner ear, Paleoneurology

Submitted:2020-09-11, published online:2021-02-03. https://doi.org/10.18563/journal.m3.130

$\begin{array}{llc}\text { Inv nr. } & \text { Taxon } & \text { Description } \\ \text { MUCPV-205 } & \text { Limaysaurus tessonei } & \begin{array}{c}\text { Renderings of the } \\ \text { virtually isolate } \\ \text { braincase, brain, } \\ \end{array} \\ & & \text { and right inner ear. }\end{array}$

Table 1. Related model. MUCP: Museo de la Universidad Nacional del Comahue, Argentina.

\section{INTRODUCTION}

Rebbachisaurids are sauropod dinosaurs that lived from the lower to the upper Cretaceous of South America, Europe and Africa (Bonaparte 1997; Upchurch et al. 2004; Apesteguia et al. 2010; Whitlok 2011, Mannion \& Barret 2013). However, braincase remains of these sauropods are scarce, being known only for Nigersaurus taqueti from Africa (Sereno et al. 1999, 2007), and Limaysaurus tessonei (=Rebbachisaurus in Calvo \& Salgado 1995) and an unnamed rebbachisaurid (Paulina-Carabajal et al. 2016) from Argentina. The cranial endocast and inner ear of L. tessonei is the most complete paleoneurological data for a rebbachisaurid sauropod so far (Table 1 and Fig. 1).

\section{METHODS}

The 3D surfaces were extracted semi-automatically within MIMICS 18.0 using the segmentation threshold selection tool. The 3D surface models are provided in .ply format, and can therefore be opened with a wide range of freeware.

\section{ACKNOWLEDGEMENTS}

Grant sponsors: 1. Agencia Nacional de Promoción Científica y Tecnológica, 2. Universidad Nacional del Comahue. Grant numbers: 1. PICT-2016-0481 to AP-C, PICT 2911/2591 to JOC; 2. $04 / \mathrm{I} 082$ to JOC.

\section{BIBLIOGRAPHY}

Apesteguía S, Gallina PA \& Haluza A. 2010. Not just a pretty face: anatomical peculiarities in the postcranium of rebbachisaurids (Sauropoda: Diplodocoidea). Hist Biol 22: 165-174. https: //doi.org/10.1080/08912960903411580

Bonaparte JF. 1997. Rayososaurus agrioensis Bonaparte 1995. Ameghiniana 34: 116.

Calvo JO, Salgado L. 1995. Rebbachisaurus tessonei sp. nov. A new Sauropoda from the Albian-Cenomanian of Argentina; new evidence on the origin of the Diplodocidae. Gaia 11: 13-33.

Mannion PD, Barret PM. 2013. Additions to the sauropod dinosaur fauna of the Cenomanian (early Late Cretaceous) Kem Kem beds of Morocco: Palaeobiogeographical implications of the mid-Cretaceous African sauropod fossil record. Cret Res 45: 49-59. https://doi.org/10.1016/j.cretres.2013.07.007

Paulina-Carabajal A, Calvo JO 2021. Re-description of the braincase of the rebbachisaurid sauropod Limaysaurus tessonei and novel endocranial information based on CT scans. Anais da Academia Brasileira de Ciências 93(Suppl. 2): e20200762 https://doi.org/10.1590/0001-3765202120200762

Sereno PC, Beck AL, Dutheil DB, Larsson HC, Lyon GH, Moussa B. Sadleir RW, Sidor CA, Varricchio DJ, Wilson GP, Wilson JA. 1999. Cretaceous sauropods from the Sahara and the uneven rate of skeletal evolution among dinosaurs. Science 286 (5443): 1342-1347. https://doi.org/10.1126/science.286.5 443.1342 

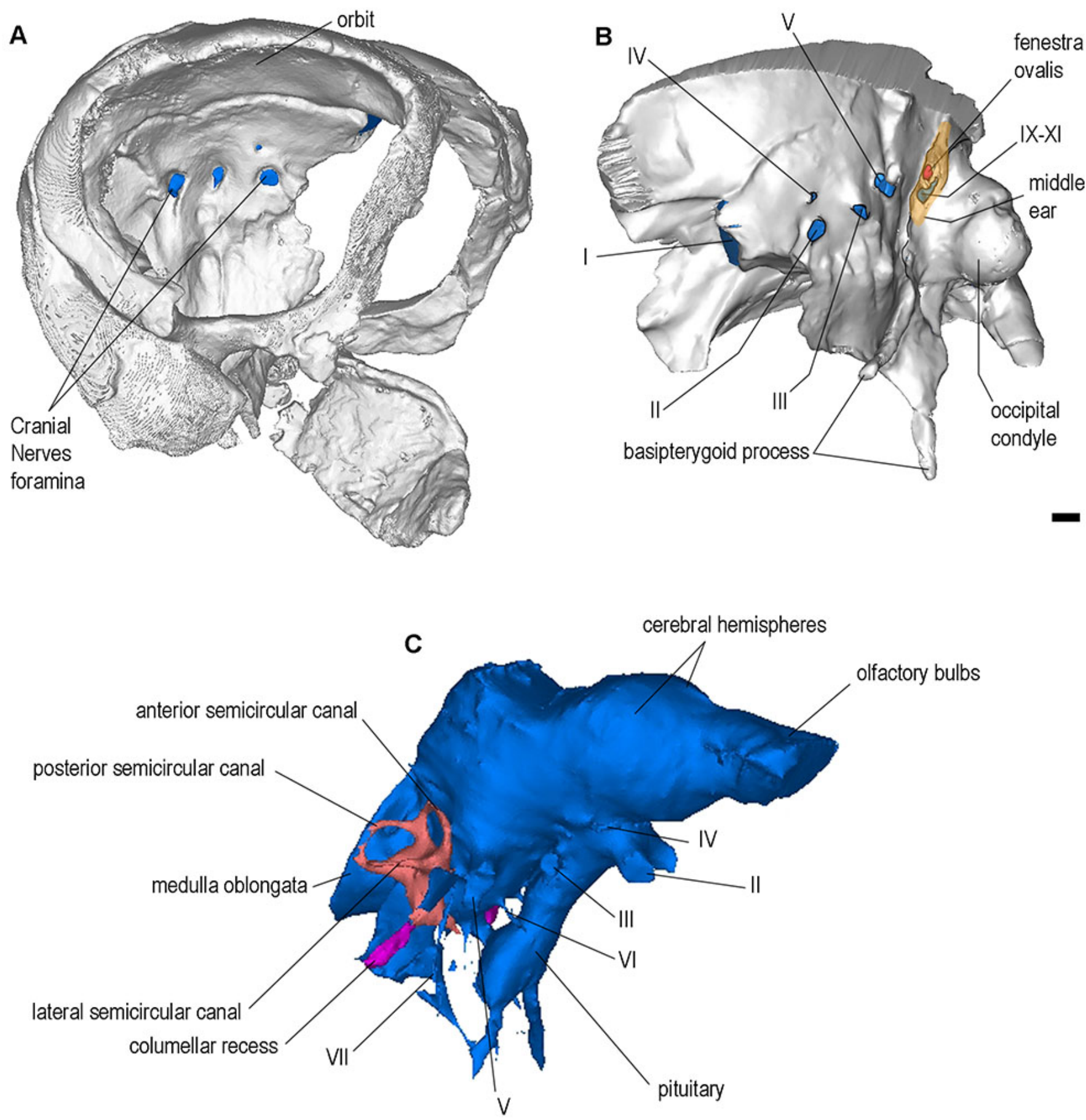

Figure 1. Renderings of the braincase and other articulated bones of Limaysaurus tessonei MUCPv-205 in right lateral (slightly anterior) view (A); braincase (lateral margins of the orbit and other articulated skull bones were removed to allow observation of the complete lateral wall) in left lateroventral view; cranial endocast in right lateral (slightly anterior) view (C). In the right image, the bones are semitransparent to allow observation of the brain and inner ear. Scale bar in A and B equals $10 \mathrm{~mm}$. 
Sereno PC, Wilson JA, Witmer LM, Whitlock JA, Maga A et al. 2007. Structural extremes in a Cretaceous dinosaur. PLoSONE

2(11): e1230. https://doi.org/10.1371/journal.pone.0001230

Upchurch P, Barrett PM, Dodson P. 2004. Sauropoda. In: Weishampel et al (Eds), The Dinosauria, Berkeley, University of California Press, p. 259-322. https://doi.org/10.1525/c alifornia/9780520242098.003.0015

Whitlock JA. 2011. A phylogenetic analysis of Diplodocoidea (Saurischia: Sauropoda). Zool J Linn Soc 161: 872-915. https: //doi.org/10.1111/j.1096-3642.2010.00665.x 